\title{
IS THE ETHICS OF ECONOMIES ADAPTED OR NOT TO THE IMPERATIVE OF BIOETHICS
}

\section{Dejan Donev ${ }^{1}$}

Review paper

Institute of journalism, media and communication, Faculty of law "Justinijan I", University "St. Cyril and Methodius", Skopje

Received: 21.03 .2012

UDC: $174: 330$

Accepted: 09.07.2012

\begin{abstract}
The ethics in economy is not only a corrector, but also must be initiator if we want to achieve essence of our existence - the human being as "Homo ethicus", as well as, which is more important for mankind - to achieve a human being as "Homo homine ethica ethicus est". This remark points on two things. First: we came to the stage where we become aware about the fact that our economies are dehumanized. The second: that's the reason why we must return to ethics and pull out from it that universal values which will make the managers of natural recourses more ethically awarded, so they will be able to start managing production without endangering bio potentials anymore. Previous remark lead us to conclusion that, no matter if the idiom "business ethics" is oxymoron or not, the present ethics is more a list of rules of conduction or, more precisely, etiquette. This clearly points that this kind of ethics of economy and in economy is not adoptive to the imperative of Bioethics: Don't misuse recourses if you want to feed yourself and those for which you create the existence! This is so because always when we talk about ethics and ethicizing of those which managing the base of existence, de facto, are discussions about choosing the appropriate model of capitalism. The problem of these "discussions" is that we almost always forget to explain: is the chosen model of capitalization of society applicable considering the local specifics and needs of community? Therefore, the imperative of Bioethics, in this context, is to teach the ethics how to think about bio resource and bio heritage, even if we stop talk of some kinds of ethics and ethicizing of economies and of those which managing with it, because if we reconsider the reactions of the population, it is clear that they are seek of talking about it. But also, it's recognizable the fact that they who talks just show that the essential thinking about Bioethics is absent and that the Bioethics, de facto, is a tabby. This fear from true talking and essential declaring origins from fear that thinking about the biohumanization of economy consequently will result with change of awareness and conscience about ethics, in general.
\end{abstract}

${ }^{1}$ Correspodence to:

Dejan Donev, Institute of journalism, media and communication, Faculty of law "Justinijan I", University "St. Cyril and Methodius", Skopje, and also Institute of philosophy, Faculty of philosophy, University "St. Cyril and Methodius", Skopje, Republic of Macedonia

Skopje, Republic of Macedonia

E-mail: donevdejan76@gmail.com 
IS THE ETHICS OF ECONOMIES ADAPTED OR NOT TO THE IMPERATIVE OF BIOETHICS

There is no doubt that ethics of management exists in whatever form, and that is a fact! The dispute comes in the moment when we ask ourselves about what kind of ethics we are talking about, how it is used, and what is even more important, why doesn't give us the results we expect from it ${ }^{2}$. For having no misunderstanding about the results which ethics should give, at the very beginning we should say that: Ethics in economy should not only be a corrective, but also a starter, a basic energy, if we want to come to what should be the essence of our existence - the Human, but not only as Homo ethicus, but also, which is more important for us as a kind, as Homo homine ethica-ethicus est!

This may sound unusual, the motive of the text and the conclusion to be given in the lead, but I have chosen this kind of access with intention to present the facts I have come to, investigating up till' now the usage of, and have to say unfortunately, misusage of the word "Bioethics".

The following text is not only because of the previously said, but even more for the fact that we must stop counting the conditions in which we want or dream of ethics to determinate us and by starting revaluation and redistribution of the universal ethical values to put ourselves and the man in general to the fact that it must rise to the real self-conscious (bio)ethical being which acting would open space for the type of human existence in which we will never more ask ourselves do we have indeed, and if we do, what kind of ethics we have in management. The using of this kind of questioning is because we live in a time, where from one side, the myth of amorality of the business, and by that the myth of managers, still exist. Yet, it is more than obvious that this attitude is filled with the assertion that the notion "business ethics" is an oxymoron in its essence.

\footnotetext{
${ }^{2}$ For further see Karpati (2001).
}

This gives right to those which are comfort not analyzing, to state and rise to the level of science with the allegation that morality-ethics is determinated by personal interest - profit $^{3}$.

Talking about the moral and business, and about the way of its managing, and thought that for the moral of those which just moralize about them, it is very clear that actually it is about whether it is chosen this or that model of capital-capitalism; this or that type of arranging; this or that social and collective consciousness. But what in essence is concerning, is the fact of avoiding the determination-declaration of the model of the practiced capitalism, in relation to whether it is productive or it is not, but not in sense of achieved remnants, but in sense of whether the chosen model produces such economical base of existence which would open space and time in eventual leisure of realized free time for everyone of those which participate in those processes, to question whether that model is ecological, more precisely bioethical and justified.

This statement, unfortunately, is carried out from the knowledge that in the past analysis of the practiced model of capitalism the focus was set on finding arguments that this kind of model is successful, and that gives positive ethical results if respects the following values: individual's autonomy; fulfilling obligations toward promised; protecting sincere profit-ownership, as well as the tacit understanding of the fair-play rules in aim of achieving certain level of "confidence".

There is no dispute that in these comments and analysis much of the attention is paid to core ethical values. Their disadvantage is that in assessing the justification of the selected model they are starting from the fact how much the selected model is in conformity with the interests of maintaining manufacturing supply (in terms of maintaining the physical strength of bare manufacturer), instead of assessing the function, capital and the reproduction of the selected models in terms of economy in which they should be realized, namely whether or not select models will create conditions for a new economy that would be in symbiosis with ethics ${ }^{4}$.

${ }^{3}$ Further see Radermacher (2003).

${ }^{4}$ The same, also Klose (1996). 
To avoid the possibility of being perceived as one of many diagnostician-lamentator, and coming from an environment in which the hunger for participation in global processes of everyday life and politics that determine everyone and everywhere, and where the results of production are determined - it must be asked: why and how there is so much talking for some kind of globalization? What is more important than that, arises the question: what do we globalize about, or what it should be globalized about for the world to come to what we really need in essence? This questioning arises especially when we are talking about what, like it or not, determines the degree of our freedom of conscience ${ }^{5}$. More precisely, the questioning is in relation to economy, or, said in today's colloquial political marketing terms, what kind of globalization is at question, that should serve as an exit from the alleged closure of the development?

Searching for an answer, this conclusion offers by itself the following:

First of all, in what is now called economics, business, economy, both locally and globally, there is a variant called practice i.e. a capitalist's system in which the things you can look forward to, if you look in their legislation, are the proposals that can be found, different solutions and ways of their adaptation to the more pervasive demand which becoming an imperative that these models, in whatever way, must be bio-ethicized in a bigger manner.

What is more important than previous observations, regarding the level of development of the participants in such economies, it is obvious from the universal aspect of human existence, that the globalization is a requirement, a needness. But, let's not forget that this conscious is expressed not as a knowledge that the global economy of variant market is needed. The only thing worrying here is the fact that this idea of a global economy is not based on the idea that this kind of globality can only happen if the economy is perceived as an economy based on fundamental mutual agreement, the allocation of creating a common market in the world ${ }^{6}$.

\footnotetext{
${ }^{5}$ About these problems and role and meaning of ethics it is useful to look Singer (2005).

${ }^{6}$ Further see Šimleša (2006).
}

Unfortunately this shows the fact that ethics, no matter how convenient it is applied, the very fact of its existence, thrives, despite all the limitations to change conscience of all of us about everything around us, no matter looking at everyone in their community's situation, sometimes we feel/consider ourselves as futility. I would not like to sound like someone who doubts in the necessity of this kind of analysis, where, even emotionally, it can be reproach about what really concerns us on the road to what and why in its existence as authors we are determined to - that with words and what it can be contributed if excused using own words, in another words to inspire basics for bioethical way of thinking - but with the statements above I just want to point out that if we really do not stop writing prescriptions and get into practical acting, we will not make it to where we are headed - YES for a global world! YES, for global economy. But only in the function of an economy and a functionalized ethics that will allow us bio-ethicalization, as a way of existence and as a way of birth.

However, in order to come to the real existence as bioethicing, above all we must overcome a situation in which is persistently talked about ethics. This usually do those which manage our existence avoiding to recognize the fact that it has been started to talk about ethics so much, justified or not, that this induces a feeling of saturation into people, not to say hostility to those concerned with the topic.

A little discourse here. It has to be said that to this kind of a situation we came as much as because of the needs of those who manage to conceal the essence of the problem, as well as because of the absence of essential talk about ethics in economy-managing, and even more because such a declaration is essentially afraidness to talk about taboo topics. This fear of essential clarification is a product of the fearness of fundamental thinking about ethics of economy which must necessarily come to changing the awareness of ethics itself.

Following the logic of ethics and taking into consideration current attitudes about the importance of ethics, and what in the very essence of ethics itself, regardless of how it is used or misused, from the previous exposures it is clear the necessity of developing the ethics of responsibility for the sake of own bio-future. 
Developing such liability is a sine qua none, and without which it is impossible for ethics to fulfill basic tasks, objectives, functions of human existence: to be a preventive element for the eventual dehumanization in economies that are evident, either locally or globally, that are not following the only possible ethics - being aware that with our creation and deciding we will survive as a species aware for responsibility not only for biomass, but also for the biological potentials of it. This clearly indicates that we no longer need special ethics of management and managing that are de facto decorum of market behavior, but we need ethics in economy, as a prevention that would be mindful of the effects all the time, i.e. every decision and act will be guided from the necessity to go forward to existences which will be determined toward bio-ethical values.

I believe that I have no need to explain that all previously spoken points that the production, both locally and globally, must move to a new way of organizing from where it will come to a new organization and companies, and new organization as a way of creating (Draker, 2000, pp. 12-49). The insisting that it must move to a new way of organization is not only because of the need to survive, but to create conditions in which economy will not be determined toward political conditions-system. This means that this new organization must lead to avoidance, prevention of possible political conflicts and to open space for real thinking on the subject: what remainings of the nature do we have, how to compensate her, and how to leave as a heritage, a quality ethics, for those that will come after us, developed and applied of a certain awareness that the biomass is our mother and Savior whom we will not crucified as before.

Insisting on the reorganization of the organizations is with purpose to create conditions in which it will be possible to raise the level of quality of life based on the valuation of life as a superior bioethical value. To be clear, what I strive for is an ethical man who would always and everywhere be aware of the significance of its decisions and consequences for itself and for the others. This kind of awareness and self-conscious about its own place and presence of the others, gives right to conclude that managing is impossible if management is determined by direct and subordinate goals of daily economy and politics. Under these terms, ethics would, in normative sense, become a science-instruction-determination of the proper (ethically responsible) action and decision-making. On this way only ethics would become what we require to be, an "instruction" for taking into consideration the consequences caused by decision by what we all owe are existence to - the biomass.

All previously said leads to precisely those conditions through which and on which the question of bioethicallity in economy refracts to. Also this speaks that ethichisizing the decision making process and its manifestation is the key on the road to real bioethics. But, this will happen when the starting point will be the claim that it doesn't exist for itself and because of itself, and according to that, neither we for itself, but that exist for us a because of us so we can realize as truly ethicus based on real bioethical choices ${ }^{7}$.

A sentence constructed like this, is not only for pointing out facts that reaching Bioethics is impossible without prior terminological-semantic solution of the chaos in the (mis)use of words related to ethics or words that contain auspice of ethics. I have put together the sentence in that way, because we often encounter with "socialized" ethics, which, de facto, ends in the establishing or claiming valuesystems which will allow order in which economic and social relations of the human, would be appropriate, suitably structured by its degree - a degree taken here as a measure that allows commodity and constitutions, named "moralizing".

To avoid falling into abuse of the terms and the blurring of reality with them, I think it is quite clear that we need re-deployment of the hierarchy of meaning of certain fundamental values of ethics, as a necessary precondition for the democratization of relations in the creation of existence on the road to democracy, not by fiat, but democracy based on agreement. The notion "democracy does not by fiat but by consent" shows by itself why do I insist on this kind of distinction.

${ }^{7}$ About these problems and possible answers see Sachs (2007). 
Specifically, it is so because the ethics of which we stand for, that must lead us to bioethics as a reason of existence and production, is impossible without democratization understood as a redistribution and allocation of power in making decisions-managing on the road toward democracy for everybody. It is founded on the awareness of bioethical consequences of the so far present way of practicing the making decisions-managing, which until today was more of a practice of denying the universality of bioethical values.

Perhaps this can astonish someone, but to point out immediately, this is because I insist on revaluation on all the values-categories, in order to reach the truly, not only bioethical managing and management, but true bio-ethicing. This means that with all the previous, I insist on establishing a real network of the role of ethical values. Insisting on a real network of the roles of ethical values, comes from the fact that by its establishing it can be understood why and how happened "the meaning of bioethics which stems from the fact that vital issues have become the first issue of ethics today and will be in the next epoch" (Temkov, 2004, p. 184). This is because there is no system of ethical values if we forget that no value is for itself, but in an ongoing feedback with all other values, from where comes a network of values needful for the ethics I strive for, and consider is as the only possible: an ethics which by networking universal values, can only lead us to bioethics as all-measuring and all-existing reason and cause of producing conditions and basis, and now bio-existence.

What is previously said, is also because of the need to be asserted, and thus bringing value of which and with whom we not only exist, but also determines us: an Ethics which by its essence will make such an economy that will no longer be a production of ethical preconditions for ethic's existence, but what needs to be - a school for bio-ethicing. Still, a larger value from this, will be the fact that we will no longer have to explored and compiled practical ethics-decors, but the level of determination of ethics would allocate the ethicallity of practice one. And hence, the following: ethics in managing and management will become ethics of bioethicing because of the basic duties and func tions - creating conditions for existence that would be practical demonstration and proof of what we loudly and clearly demand and need: YES for ethics! But, ethics that before becoming as such, it must rise to Bioethics!

\section{REFERENCES}

Draker, P. (2000). Menid 'ment predizvikatelstvata prez 21 vek. Sofija: Klasika i Stil.

Karpati, T. (2001). Etika i gospodarstvo. Croatia, Osijek: Ekonomski fakultet - Grafika.

Klose, A. (1996). Poduzetnička etika. Croatia, Zagreb: Školska knjiga.

Radermacher, J. F. (2003). Ravnoteža ili razaranje: Ekosocijalno-tržišno gospodarstvo kao ključ svjetskog održivog razvoja. Croatia, Zagreb: Intercon-Nakladni zavod Globus.

Sachs, J. (2007). Kraj siromaštva:Ekonomske mogućnosti našeg doba. Zagreb: Algoritam.

Singer, P. (2005). Jedan svijet:Etika globalizacije. Croatia. Zagreb: Ibis grafika.

Temkov, K. (2004). Etika za III godina. Republic of Macedonia, Skopje: Prosvetno delo.

Šimleša, D. (2006). Četvrti svjetski rat: Globalni napad na život. Croatia, Zagreb: Što čitaš?. 